\title{
Topical Application of Cudrania tricuspidata Stem Extract Inhibits Atopic Dermatitis-Like Skin Lesions in an NC/Nga Mouse Model: An Experimental Animal Study
}

\author{
Yoo-Sin Park ${ }^{1,2,3}$, Shin-Hee Kim ${ }^{4,5}$, Sang-Yeon Kim, ${ }^{4,6}$ Gae-Myoung Koh ${ }^{4}$, Ju-Hwan Suh7, \\ Ju-Seop Kang $1,4,5,6,8^{*}$ \\ ${ }^{1}$ Division of Molecular Therapeutics Development, Hanyang Biomedical Research Institute, Hanyang University, \\ Seoul, Republic of Korea \\ ${ }^{2}$ Department of Clinical Nutrition, Shintong Rehabilitation Clinic, Yongin, Republic of Korea \\ ${ }^{3}$ Department of Food \& Nutrition, Hanyang Women's University, Seoul, Republic of Korea \\ ${ }^{4}$ Department of Pharmacology, College of Medicine, Hanyang University, Seoul, Republic of Korea \\ ${ }^{5}$ Institute of Medical Science, Hanyang University, Seoul, Republic of Korea \\ ${ }^{6}$ Department of New Drug Development, College of Medicine, Hanyang University, Seoul, Republic of Korea \\ ${ }^{7}$ Department of Biology, Johns Hopkins University, Maryland, USA \\ ${ }^{8}$ Department of Bioengineering, College of Engineering, Hanyang University, Seoul, Republic of Korea \\ Email: "jskang@hanyang.ac.kr
}

Received 2 August 2016; accepted 28 August 2016; published 31 August 2016

Copyright () 2016 by authors and Scientific Research Publishing Inc.

This work is licensed under the Creative Commons Attribution International License (CC BY).

http://creativecommons.org/licenses/by/4.0/

c) (i) Open Access

\section{Abstract}

Atopic dermatitis (AD) is a chronic inflammatory skin disease characterized by elevated immunoglobulin E (IgE), mast cell infiltration and skin lesions including pruritus, erythema and eczema. Cudrania tricuspidata extracts have been clinically administered for a long time in the East Asia including Korean and China as a home-remedy to diminish the inflammation of gastritis and hepatitis. To examine whether it works on AD or not, an AD-like animal model was experimented in this study. AD was induced by applying Dermatophagoides farinae (D. farinae) extract to the backs of 9-week old NC/Nga mice for 21 days. Following this, an ethanol extract of $C$. tricuspidata stems (EECT) was applied topically for 14 days to the sensitized skin, while distilled water was used as a control (EECT0 mice). Anti-AD effects of EECT were evaluated using scores for AD-like skin lesions, serum IgE levels and mast cell counts in the skin dermal layers to assess inflammation. Topically applied ethanol extract of Cudrania tricuspidata stems (EECT 7.5, 25 and $75 \mathrm{mg} / \mathrm{mL}$ ) markedly reduced $A D$-like skin lesions after 4 days (by $30.1 \%, 31.4 \%$ and $38.5 \%$, respectively) and also after

${ }^{*}$ Corresponding author.

How to cite this paper: Park, Y.-S., Kim, S.-H., Kim, S.-Y., Koh, G.-M., Suh, J.-H. and Kang, J.-S. (2016) Topical Application of Cudrania tricuspidata Stem Extract Inhibits Atopic Dermatitis-Like Skin Lesions in an NC/Nga Mouse Model: An Experimental Animal Study. Pharmacology \& Pharmacy, 7, 358-367. http://dx.doi.org/10.4236/pp.2016.78044 
14 days (by $63.6 \%, 66.1 \%$ and $49.6 \%$, respectively), while distilled water improved AD by $17.8 \%$ and $38.7 \%$, respectively $(p<0.05)$. Serum IgE production was reduced in the EECT7.5, EECT25 and EECT75 groups after 4 days (by 57.6\%, 65.9\% and 59.3\%, respectively) and after 14 days of the treatment (by $82.0 \%, 79.6 \%$ and $75.3 \%$, respectively), while distilled water decreased it by $38.8 \%$ and $62.3 \%(p=0.0001$ and $p=0.0001$, respectively). Mast cell counts increased after sensitization by $D$. farinae extract $(\mathrm{p}=0.003)$ and EECT attenuated the mast cell overproduction, and reduced mast cell degranulation markedly. Attenuation was most obvious in the early stage of EECT treatment when the AD was most acute.

\title{
Keywords
}

\author{
Atopic Dermatitis, Cudrania tricuspidata Stem, Dermatophagoides farina, Immunoglobulin E (IgE), \\ NC/Nga Mouse
}

\section{Introduction}

Atopic dermatitis (AD) is a chronic inflammatory skin disease accompanied by representative symptoms such as itch, erythema, excoriation, edema, dryness and scaling [1]. It is very prevalent in infants and nowadays has also spread to adolescents and adults. Its causes are not fully understood, but inflammatory dysregulation of the immune system of the skin and mucous membranes in response to allergens is probably involved. This immunologic disturbance is reflected in elevated serum immunoglobulin E (IgE) resulting from increased inflammatory cell infiltration into the skin, and is dominated by type2 helper T-cells [2]. Accordingly, AD is characterized by histopathologic skin changes and dermatitis lesions of the face, neck, head, arms, knees and elbows. Therefore, sensory evaluation of the disturbance caused by such skin lesions or determination of IgE levels is used to diagnose or evaluate $\mathrm{AD}[3]$.

We examined a natural material with anti-inflammatory effects as a new drug candidate for AD treatment. The selected natural material was extract of Cudrania tricuspidata (C. tricuspidata), a kind of mulberry tree which is native to East Asian countries such as Korea, China and Japan [4]-[7], and occurs mainly in the southern area of South Korea [5]. Extracts of the fruit, leaves, root-bark and stems of $C$. tricuspidata have been traditionally used for hepato-protection [8]-[10], and as anti-hypertension [11], anti-diabetes [12] [13], anti-allergy [14] and antioxidation [15]-[17] treatments in Korea. Well-known physiologically active compounds of C. tricuspidata are isoflavones and flavonoids from the fruits [18], gerontoxanthone, cudraflavone B, gericudranin, cudraxanthones, isocudraxanthones, some flavanones and macluraxanthone from the roots [9] [19], kaempferol and kaempferolD-glucopyranoside from the leaves [20], and kaempferide-D-glucopyranoside and naringenin-D-glucopyranoside from the stems [21]. However, the anti-AD effects of $C$. tricuspidata have not been studied except for a recent report using fruit extract [22]. Therefore, we examined the therapeutic effect of ethanol extract of $C$. tricuspidata stems (EECT) on AD symptoms when administered topically in an NC/Nga mice AD model induced by Dermatophagoides farinae (D. farinae) extract.

\section{Materials and Methods}

\subsection{Preparation of the EECT}

Dried stems of $C$. tricuspidata were finely powdered, and biologically active compounds were extracted with 95\% ethanol $(1: 10, \mathrm{v} / \mathrm{v})$ for $24 \mathrm{~h}$, in a $60^{\circ} \mathrm{C}$ water bath, then filtered through filter paper (ADVANTEC No.2, $150 \mathrm{~mm}$ ) under vacuum. The filtrate was concentrated by evaporation at $45^{\circ} \mathrm{C}$, then deep-frozen at $-70^{\circ} \mathrm{C}$ after reconstitution in $70 \%$ ethanol in a concentration range of $100-200 \mathrm{mg} / \mathrm{mL}$. The frozen filtrate was diluted appropriately after thawing to room temperature. Three concentrations of the ethanol extract (EECT) namely 7.5, 25 and 75 $\mathrm{mg} / \mathrm{mL}$, were prepared by diluting with distilled water, and tested topically.

\subsection{Induction of AD-Like Skin Lesions in an NC/Nga Mouse Model}

Twenty-eight NC/Nga mice (9 week-old, male) were purchased from Central Exp. Animals Co. Ltd. (South Ko- 
rea), and all animal procedures were approved by the Institutional Animal Care and Use Committee of Hanyang University (No: HY-IACUC-10-062). After one-week of adaptation, the mice were anesthetized with ether and their heads, necks and shoulders shaved with razors and waxing cream. Then twenty-four of the mice were topically administered $100 \mathrm{mg}$ of $D$. farinae (house mite) extract-ointment (Biostar AD ointment, Japan) on their shaved skin regions six times over 21 days to induce AD-like skin lesions [23]. 4\% SDS solution was used to brush their shaved skin instead of waxing cream after the first administration of house mite extract [23]. On the 21st day, the severity of the AD-like skin lesions was evaluated. Eight mice died during the AD induction period during waxing and sensitization, and the remaining twenty mice were divided into five groups.

\subsection{Treatment on the AD-Like Skin Lesions with EECT}

On the 21st day EECT was administered to three experimental groups of 4 mice receiving $7.5 \mathrm{mg} / \mathrm{mL}, 25 \mathrm{mg} / \mathrm{ml}$ and $75 \mathrm{mg} / \mathrm{mL}$ EECT, respectively, for 14 days. The EECT was topically applied with a small flat brush once a day on all the treated skin areas. Distilled water was administered to the control group (EECT0, $n=4)$ in the same manner, while the "normal" group (normal, $n=4)$ received no treatment.

\subsection{Changes of AD-Like Skin Lesions}

The changes of the AD-like skin lesions were assessed visually by two trained investigators on the 21st day of sensitization, and after the $4^{\text {th }}, 10^{\text {th }}$ and $14^{\text {th }}$ day of EECT treatment. The severity was scored as the sum of the $\mathrm{AD}$ scores for each category, namely itch, edema, erythema/hemorrhage, excoriation/erosion and dryness/ scaling, graded as 0 (no symptoms), 1 (mild symptoms), 2 (moderate symptoms) and 3 (severe symptoms) [24][26]. Then the AD score for each group was converted to "AD reduction (\%)" calculated from the equation \{(AD score at baseline $-\mathrm{AD}$ score at the 4 th, 10th or 14th day of EECT treatment $) / \mathrm{AD}$ score at baseline $\} \times$ 100.

\subsection{Changes of Inflammation Measured from Serum IgE Levels}

Orbit blood was collected under ether anesthesia on the final day of AD induction, then on the $4^{\text {th }}, 10^{\text {th }}$ and $14^{\text {th }}$ days of treatment. Sera were deep-frozen at $-70^{\circ} \mathrm{C}$ after centrifugation of blood at $3000 \mathrm{rpm}, 4^{\circ} \mathrm{C}$ for 20 min. Serum IgE levels were determined using a Mouse IgE ELISA Assay kit (XpressBio Life Science Products, Catalog No: 595-700, Express Biotech International, Thurmont, USA) at $450 \mathrm{~nm}$ expressed as (serum IgE level at baseline - serum IgE level on the 4th, 10th or 14th day of EECT treatment)/serum IgE level at baseline $\} \times 100$.

\subsection{Histopathologic Evaluation}

After the 14 days of EECT treatment, all the mice were killed under ether anesthesia after evaluation of the AD-like skin lesions and orbit blood sampling, and the skin was removed from the affected regions of the animals' heads, necks and shoulders. The skin was fixed with $10 \%$ formaldehyde, embedded in paraffin, and thin sections were made. The sections were stained with toluidine blue $\mathrm{O}$, and microscopic examination was carried out at $\times 200$; the total numbers of mast cells including granulated and degranulated forms were counted at five sites $\left(400 \mu \mathrm{m}^{2}\right)$ chosen at random in each skin sample [26]-[28].

\subsection{Statistical Evaluation}

The measurements on the five groups were compared by one-way ANOVA and by post-hoc Duncan or Scheffe test at $\mathrm{p}<0.05$ using SPSS ver. 21.0. Eight mice died due to excess anesthesia during the AD induction period.

\section{Results}

\subsection{The Therapeutic Effects of EECT on AD-Like Skin Lesions}

The changes of AD-like skin lesions from the baseline at the end of AD induction to the 14 days after the EECT treatment are presented in Figure 1(a). AD-like skin lesions were reduced by the 14-day EECT treatment 
(Figure 1(b)), and significant reductions compared to EECT 0 were noted after 4 days of treatment only with 25 and $75 \mathrm{mg} / \mathrm{mL}$ EECT ( $\mathrm{p}=0.0001)$, even though EECT 7.5, 25 and $75 \mathrm{mg} / \mathrm{mL}$ were equally effective $(30.1 \% \pm$ $2.4 \%$ vs. $31.4 \% \pm 6.7 \%$ vs. $38.5 \% \pm 2.7 \%$ ). The extent of the $\mathrm{AD}$ reduction increased by 14 days of EECT treatment ( $63.6 \% \pm 9.8 \%$ vs. $66.1 \% \pm 6.3 \%$ vs. $49.6 \% \pm 12.9 \%$, respectively), and to a lesser extent (from $17.8 \%$

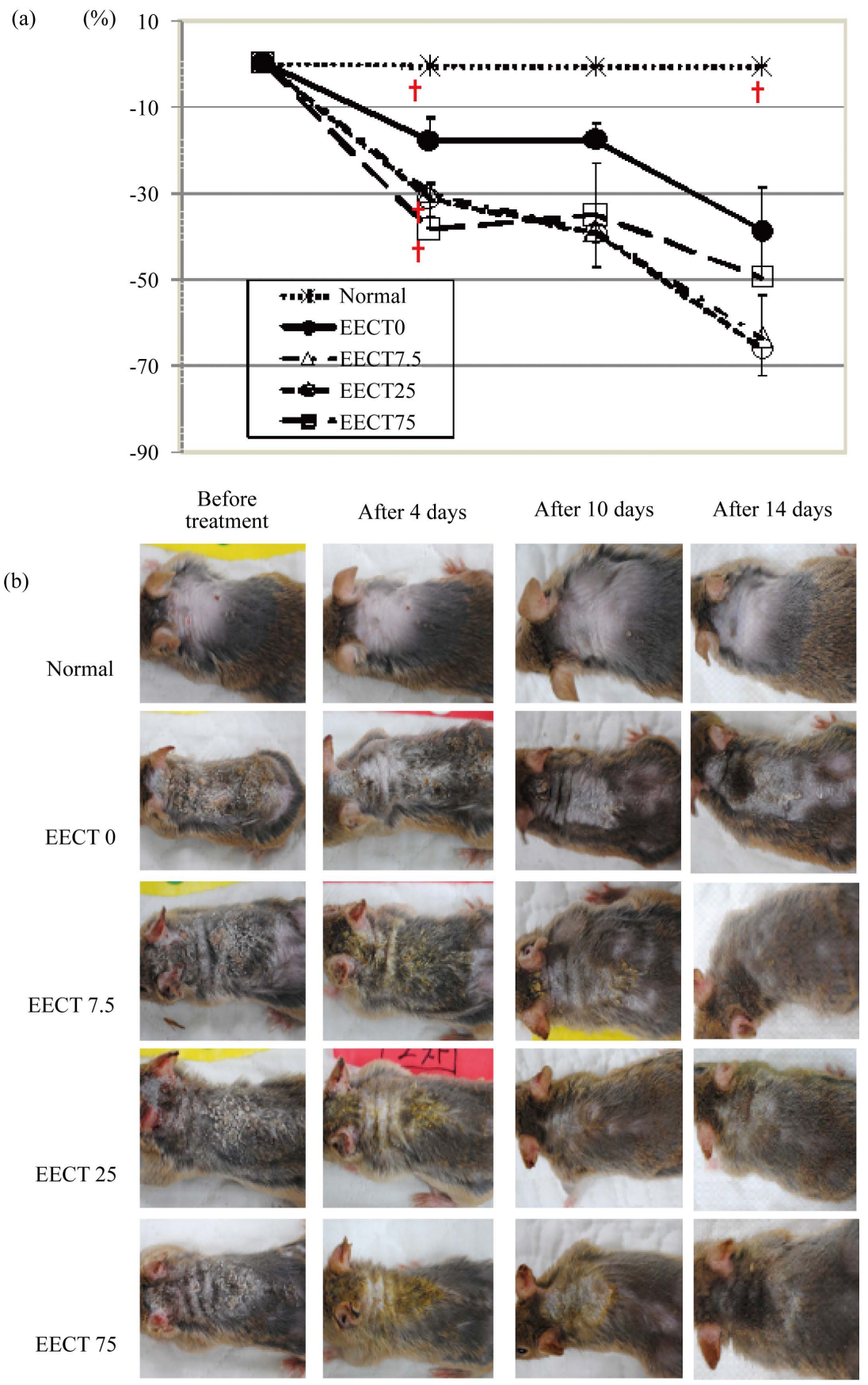

Figure 1. The changes of AD-like skin lesions from baseline at the end of $\mathrm{AD}$ induction. (a) The AD reductions (\%) in each group were compared with the EECT0 group by one-way ANOVA with Duncan's posthoc test. $\dagger$ ( $p<0.001$ ); (b) Representative photographs of AD-like skin lesions before and after EECT treatment. EECT = ethanol extract of $C$. tricuspidata stems; Normal = no $\mathrm{AD}$ induction and no EECT treatment; EECT0 = AD induction and distilled water treatement (control); EECT7.5 = AD induction and $7.5 \mathrm{mg} / \mathrm{mL}$ EECT treatment; EECT25 $=$ AD induction and $25 \mathrm{mg} / \mathrm{mL}$ EECT treatment; EECT75 $=$ AD induction and $75 \mathrm{mg} / \mathrm{mL}$ EECT treatment (mean \pm SEM, $\mathrm{n}=4$ ). 
$\pm 5.4 \%$ (4 days) to $38.7 \% \pm 9.9 \%$ (14 days)) in the EECT0 group. In spite of the higher AD reduction in the EECT-treated groups, no significant differences were found between the EECT0 and EECT-treated groups after 14 days of EECT treatment. Importantly, the AD-like skin lesions were improved most when the mice were treated with EECT $25 \mathrm{mg} / \mathrm{mL}$ for 14 days, and the therapeutic effect of EECT $25 \mathrm{mg} / \mathrm{mL}$ was significantly greater than that seen in the EECT0 group in the early stage of treatment.

\subsection{Effects of EECT on Serum IgE Levels}

The changes of serum IgE levels during the EECT treatment for 14 days are presented in Figure 2. Serum IgE levels were dramatically reduced by EECT throughout the 14-day treatment, and significant reductions (\%) were observed at each time point at 4 days $(57.6 \% \pm 7.7 \%$ vs. $65.9 \% \pm 5.2 \%$ vs. $59.3 \% \pm 6.7 \%), 10$ days $(74.9 \% \pm$ $5.1 \%$ vs. $80.4 \% \pm 4.6 \%$ vs. $74.2 \% \pm 6.7 \%$ ) and 14 days ( $82.0 \% \pm 3.7 \%$ vs. $79.6 \% \pm 6.0 \%$ vs. $75.3 \% \pm 7.4 \%$ ) of EECT treatment ( 7.5 vs. 25 vs. $75 \mathrm{mg} / \mathrm{mL})$ compared to the EECT 0 group $(38.8 \% \pm 6.9 \%, 53.9 \% \pm 10.2 \%$, and $62.3 \% \pm 7.5 \% ; \mathrm{p}=0.0001, \mathrm{p}=0.0001$, and $\mathrm{p}=0.0001$, respectively). EECT 7.5 and $25 \mathrm{mg} / \mathrm{mL}$ were the most effective doses.

\subsection{Effects on Mast Cell Counts Stained with Toluidine Blue 0}

Numbers of mast cells (both granulated and degranulated forms) in the skin dermis layers stained with toluidine BlueO were examined by optical microscopy (200×) (Figure 3) as described in Materials and Methods. Total mast cell counts were significantly increased after sensitization by $D$. farinae extract when compared to normal mice $(\mathrm{p}=0.003$; (Figure 4): normal $(153.0 \pm 7.5)$ vs. EECT0 (659.0 \pm 129.3$)$, EECT7.5 (469.5 \pm 39.2$)$, EECT25 (541.0 \pm 80.2$)$ and EECT75 $(544.0 \pm 48.8)$ ). However, total mast cell counts tended to increase less in

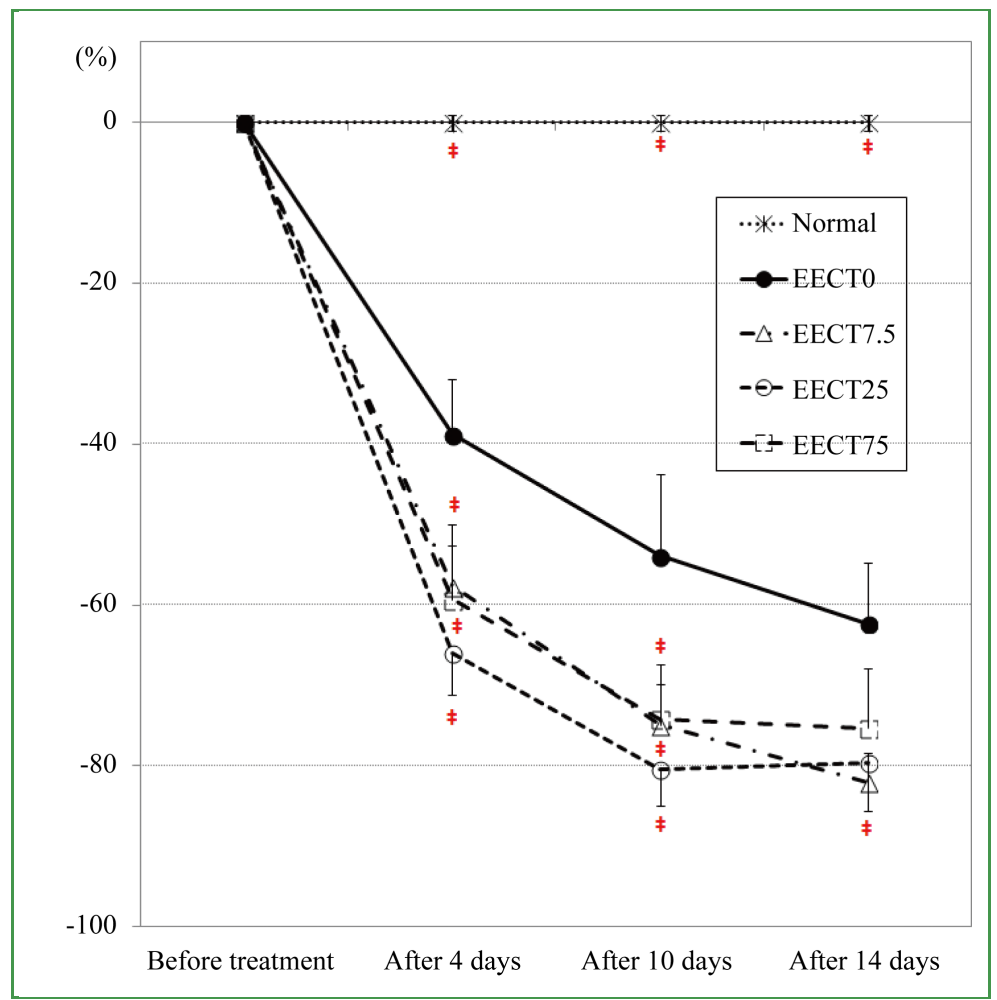

Figure 2. The changes of serum IgE from baseline at the end of AD induction. The IgE reductions (\%) in each group were compared with the EECT0 group by one-way ANOVA with Duncan's posthoc test $¥(\mathrm{p}<0.0001)$. EECT = ethanol extract of $C$. tricuspidata stems; Normal = no $\mathrm{AD}$ induction and no EECT treatment; EECT0 = AD induction and distilled water treatement (control); EECT7.5 = AD induction and $7.5 \mathrm{mg} / \mathrm{mL}$ EECT treatment; EECT25 = AD induction and $25 \mathrm{mg} / \mathrm{mL}$ EECT treatment; EECT75 = AD induction and $75 \mathrm{mg} / \mathrm{mL}$ EECT treatment (mean \pm SEM, $n=4)$. 


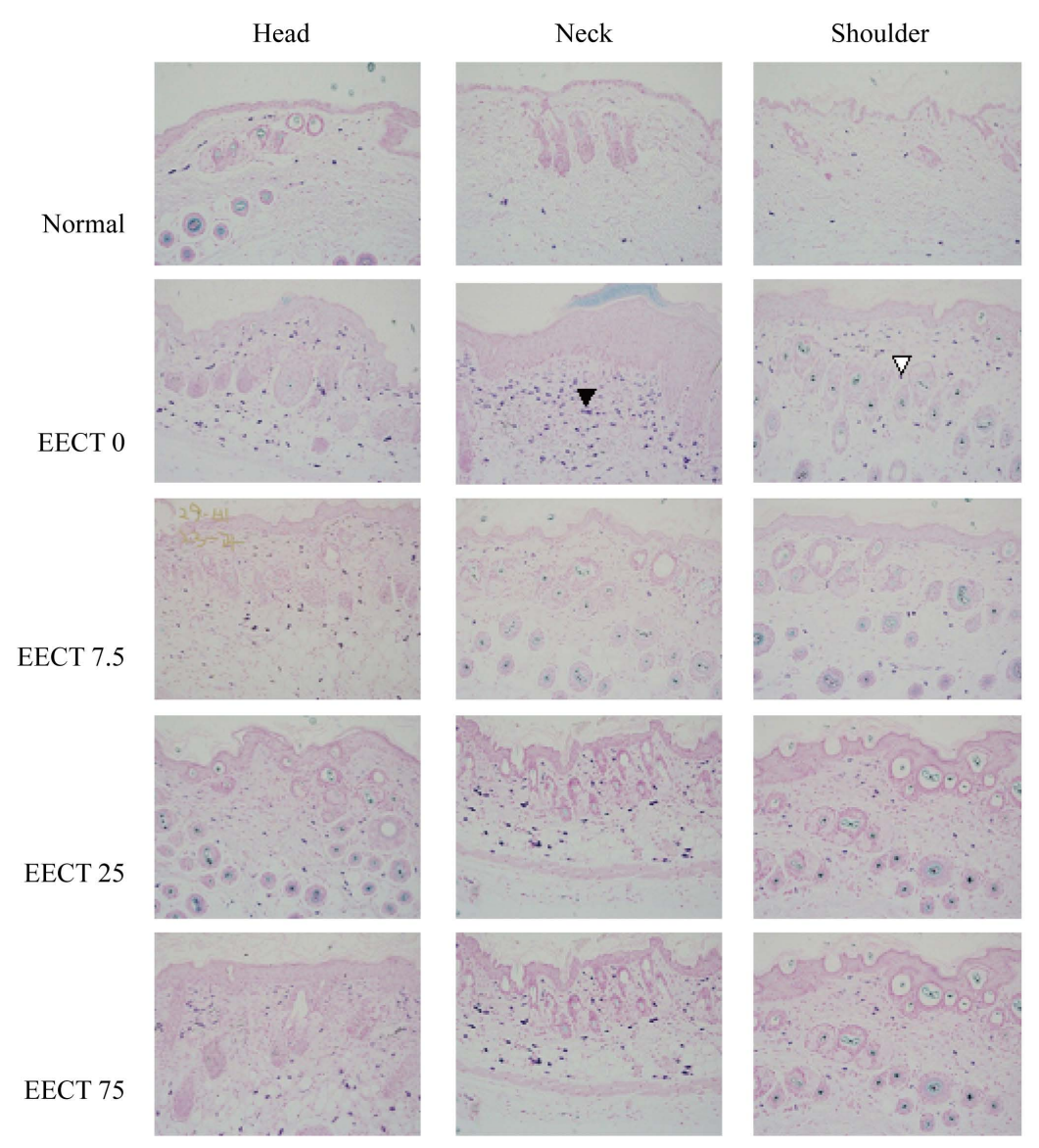

Figure 3. The representative optical microscopic images (200×) of mast cells. Granulated ( $\triangleleft)$ and degranulated ( 4$)$ mast cells in the skin dermis stained with toluidine Blue O after 14 days of EECT treatment. Other details are the same as in Figure 1 and Figure 2.

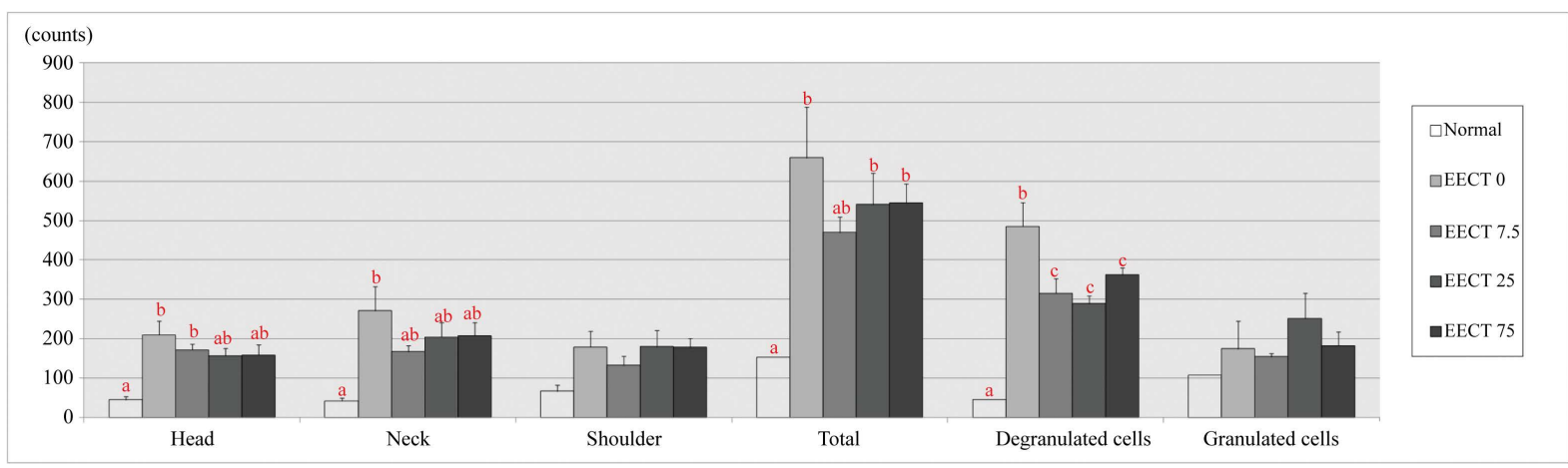

Figure 4. Mast cell counts at five sites $\left(400 \mu \mathrm{m}^{2}\right)$ chosen at random in the skin samples. Mean mast cell counts in each group were compared with the EECT0 group by one-way ANOVA with Duncan's posthoc test, and statistical differences among the groups were presented as different alphabetical scripts on the bar charts of each group at $p<0.05$ (mean \pm SEM, $n=4$ ). Other details are the same as in Figure 1 and Figure 2.

the EECT-treated groups, especially the EECT7.5 group, than in the distilled water-treated (EECT0) group. This tendency was particularly evident in the skin dermis of heads and necks. The granulated and degranulated forms of mast cells were also counted separately, and only the latter increased significantly after AD induction ( $\mathrm{p}=$ 0.0001; normal ( $45.0 \pm 8.1)$ vs. EECT0 (484.8 \pm 60.8$)$ ) while degranulated mast cells increased significantly less when treated with EECT (EECT7.5 (315.0 \pm 36.6), EECT25 (289.0 \pm 19.6$)$ and EECT75 (362.0 \pm 18.2$))$ than 
with distilled water (Figure 4). The topical use of EECT 7.5, 25 and $75 \mathrm{mg} / \mathrm{mL}$ on the AD-like skin lesions for 14 days was effective in reducing numbers of degranulated mast cells even though they did not reach the numbers in the normal group $(\mathrm{p}=0.0001)$.

\section{Discussion}

In the current study, topically applied EECT had a significant effect on the severity of AD-like skin lesions, serum IgE levels and on mast cell counts in the skin dermis. The anti-AD effects of EECT were detectible when EECT 7.5, 25 and $75 \mathrm{mg} / \mathrm{mL}$ were applied topically for 14 days to the mice (Figure 1), and these therapeutic effects are presumed to be due to diminution of systemic inflammatory reactions (Figure 2) and histopathological changes (Figure 3 and Figure 4). Natural recovery from the AD-like skin lesions was also evaluated from the results in the EECT0 group treated with distilled water. The therapeutic efficacies of EECT 7.5, 25 and 75 $\mathrm{mg} / \mathrm{mL}$ on the AD-like skin lesions were 1.7 (30.1\%), $1.8(31.4 \%)$ and $2.2(38.5 \%)$ times higher than that of EECT $0(17.8 \%)$ after 4 days $(\mathrm{p}=0.0001)$, and $1.6(63.6 \%), 1.7(66.1 \%)$ and $1.3(49.6 \%)$ times higher than that of EECT 0 (38.7\%) after 14 days of EECT treatment (Figure 1). The anti-inflammatory efficacies of EECT 7.5, 25 and $75 \mathrm{mg} / \mathrm{mL}$ on serum IgE levels were also higher than those of EECT 0 (Figure 2). The anti-AD efficacy of EECT seemed to be more significant in the early stage (after 4 days) of EECT treatment than at the later stage of treatment.

$\mathrm{AD}$ appears to be associated with inflammatory immune dysregulation of the skin, impaired skin barrier function, and IgE-mediated sensitization to food and environmental allergens such as microbial pathogens [29] [30]. Such immunologic disturbance is reflected in elevated serum IgE levels due to increased inflammatory cell infiltration into the skin, which is type2 helper T-cell-dominated, and, according to the immune dysregulation hypothesis, the defective skin barrier is interpreted as a consequence of inflammation [2]. Regardless of how to explain disease progression, the acute eczematous lesions exhibit spongiosis, hyperkeratosis and parakeratosis, and the chronic lesions are characterized by acanthosis and perivascular infiltration of lymphocytes and mast cells, and by lichenification of the skin, infiltration of Th1 cells, and tissue remodeling with increased collagen deposition and dermal thickening [30]. From this point of view, the elevation of serum IgE levels in this NC/ Nga mouse AD model was related to the onset of AD-like skin lesion development [31] [32], and also similar to that reported in AD patients with IgE hyperproduction [33]. Therefore, topically applied EECT might be very effective in reducing systemic inflammatory reactions and diverse AD symptoms such as itch, edema, erythema/ hemorrhage, excoriation/erosion, and dryness/scaling in the early stage of $\mathrm{AD}$ treatment. This suggests that patients with $\mathrm{AD}$ could obtain relief from the severe distress of $\mathrm{AD}$ symptoms more easily in the very highly induced AD state.

Many skin disorders like AD seem to be related to infiltration and activation of mast cells, resulting in skin inflammation [30] [34]. In the current study, total mast cell counts increased significantly after 21 days of sensitization (Figure 4). EECT treatment at 7.5, 25 and $75 \mathrm{mg} / \mathrm{mL}$ showed a tendency to suppress the mast cell production in the skin dermis layers of the head, neck and shoulder of the mice. This tendency to reduce dermal mast cells, specially degranulated mast cells, was significant in the EECT-treated groups $(p=0.0001)$, when compared to the EECT 0 group (Figure 4). The degranulated to granulated mast cell ratio (de-G/G) was greatly increased after $\mathrm{AD}$ induction, and the de-G/G ratio was lower after EECT treatment than after treatment with distilled water (data not shown) though the difference was not statistically significant ( $\mathrm{p}=0.162$; normal $(0.4070$ $\pm 0.042)$ vs. EЕCT0 $(6.914 \pm 4.062)$ vs. EECT7.5 $(2.049 \pm 0.257)$ vs. EECT25 $(1.308 \pm 0.235)$ vs. EECT75 (2.1880 \pm 0.357$)$ ). It has also been reported that stress-induced skin disorders due to infiltration and activation of mast cells in the skin dermis resulted in significant increases of granulated and degranulated mast cells in rats [34]-[36]. In allergic or stressed conditions, mast cells increase their IgE production [37], and degranulated mast cells that bind IgE increase [38] with a subsequent rise in histamine production, which generates severe itch and scratching of skin lesions [39]. Degranulated mast cells can initiate an acute inflammatory response and contribute to the progression of chronic diseases. Therefore, a decrease of mast cells, degranulated forms in particular, or of the deG/G ratios, in the skin is correlated with reductions of IgE and inflammatory responses, and could be a key to reducing the severity of AD-like skin lesions. Mast cells in the skin dermis of head and neck were considerably decreased by EECT 7.5, 25 and $75 \mathrm{mg} / \mathrm{mL}$ (Figure 4). This is of interest as the necks of $\mathrm{AD}$ patients were found to have higher number of mast cell profiles than any other region such as elbow, scalp and nates [3]. 
The current study has a few limitations. Thus, the considerable variability of one group resulted in limited statistical power of the comparison with the other groups. It may have been caused by the small sample size of the groups. If the sample size had been larger, the anti-AD effect of EECT 7.5, 25 and $75 \mathrm{mg} / \mathrm{mL}$ might have been more significant at 14 days of EECT treatment than that of distilled water.

In spite of the above limitation, the current study's strengths include the fact that the EECT was applied topically to the AD-like skin lesions as an ointment. Most traditional oriental natural substances, such as mulberry tree extract and ginseng are orally administered. Secondly, NC/Nga mice develop AD-like skin lesions spontaneously under normal conditions, and they are a suitable model for some aspects of human AD, with IgE hyperproduction which is influenced by environmental factors, in part, due to interleukin- 4 and -5 released by mast cells of the affected skin [31]. Therefore, the NC/Nga mouse model is useful for developing therapies for AD. In addition, it is very important to control and weaken the inflammation and dermatitis symptoms of AD, given that these unbearable $\mathrm{AD}$ symptoms are severer at night and prevalent in younger subjects. Because, $\mathrm{AD}$ is an intractable chronic disease there should be as much focus on its control as on its complete cure. From this point of view, EECT may be a possible solution to reduce AD symptoms while seeking a cure for the disease.

\section{Conclusion}

Ethanol extract of C. tricuspidata stems (EECT) administered topically to an NC/Nga mouse AD model induced by $D$. farinae extract decreased serum IgE levels and degranulated mast cell counts in the dermis of the skin, and consequently improved the AD-like skin lesions. The anti-AD effect was especially significant when EECT 7.5 and $25 \mathrm{mg} / \mathrm{mL}$ were applied for 14 days, and the therapeutic effect was more obvious in the early stage of EECT treatment when $\mathrm{AD}$ was strongly induced than later in the treatment.

\section{References}

[1] Leung, D.Y.M. (1999) Pathogenesis of Atopic Dermatitis. Journal of Allergy and Clinical Immunology, 104, S99-S108. http://dx.doi.org/10.1016/S0091-6749(99)70051-5

[2] Joo, S.S., Kim, S.G., Choi, S.E., Kim, Y.-B., Park, H.Y., Seo, S.J., Choi, Y.W., Lee, M.W. and Lee, D.I. (2009) Suppression of $\mathrm{T}$ Cell Activation by Hirsutenone, Isolated from the Bark of Alnus japonica, and Its Therapeutic Advantages for Atopic Dermatitis. European Journal of Pharmacology, 614, 98-105.

http://dx.doi.org/10.1016/j.ejphar.2009.04.047

[3] Damsgaard, T.E., Olesen, A.B., Sørensen, F.B., Thestrup-Pedersen, K. and Schiøtz, P.O. (1997) Mast Cells and Atopic Dermatitis. Stereological Quantification of Mast Cells in Atopic Dermatitis and Normal Human Skin. Archives of Dermatological Research, 289, 256-260. http://dx.doi.org/10.1007/s004030050189

[4] Cho, E.J., Yokozawa, T., Rhyu, D.Y., Kim, S.C., Shibahara, N. and Park, J.C. (2003) Study on the Inhibitory Effects of Korean Medicinal Plants and Their Main Compounds on the 1,1-Diphenyl-2-Picrylhydrazyl Radical. Phytomedicine: International Journal of Phytotherapy and Phytopharmacology, 10, 544-551. http://dx.doi.org/10.1078/094471103322331520

[5] Song, M.J. and Kim, H. (2011) Ethnomedicinal Application of Plants in the Western Plain Region of North Jeolla Province in Korea. Journal of Ethnopharmacology, 137, 167-175. http://dx.doi.org/10.1016/j.jep.2011.05.001

[6] Shi, L., Fu, Y.L. and Chen, K.S. (2007) A Novel Water-Soluble $\alpha-(1 \rightarrow 4)$-Glucan from the Root of Cudrania tricuspidata. Fitoterapia, 78, 298-301. http://dx.doi.org/10.1016/j.fitote.2007.03.007

[7] Kang, B., Liu, S., Cai, D. and Wen, Y. (2006) Species Composition and Correlation of Understory Woody Plants in Chinese Fir Plantation in the Lower Subtropical Area. Frontiers of Biology in China, 1, 423-429. http://dx.doi.org/10.1007/s11515-006-0057-0

[8] Tian, Y.H., Kim, H.C., Cui, J.M. and Kim, Y.C. (2005) Hepatoprotective Constituents of Cudrania tricuspidata. Archives of Pharmacal Research, 28, 44-48. http://dx.doi.org/10.1007/BF02975134

[9] An, R.B., Sohn, D.H. and Kim, Y.C. (2006) Hepatoprotective Compounds of the Roots of Cudrania tricuspidata on Tacrine-Induced Cytotoxicity in Hep G2 Cells. Biological \&Pharmaceutical Bulletin, 29, 838-840. http://dx.doi.org/10.1248/bpb.29.838

[10] Kim, O.K., Ho, J.N., Nam, D.E., Jun, W., Hwang, K.T., Kang, J.E., Chae, O.S. and Lee, J. (2012) Hepatoprotective Effect of Curdrania tricuspidata Extracts against Oxidative Damage. Journal of the Korean Society of Food Science and Nutrition, 41, 7-13. http://dx.doi.org/10.3746/jkfn.2012.41.1.007

[11] Kang, D.G., Hur, T.Y., Lee, G.M., Oh, H., Kwon, T.O., Sohn, E.J. and Lee, H.S. (2002) Effects of Cudrania tricuspidata Water Extract on Blood Pressure and Renal Functions in NO-Dependent Hypertension. Life Sciences, 70, 2599- 
2609. http://dx.doi.org/10.1016/S0024-3205(02)01547-3

[12] Park, J.H., Lee, K.W., Sung, K.S., Kim, S.S., Cho, K.D., Lee, B.H. and Han, C.K. (2012) Effect of Diets with Mulberry Leaf and Cudrania tricuspidata Leaf Powder Supplements on Blood Glucose-Related Biomarkers in StreptozotocinInduced Diabetic Rats. Journal of the Korean Society of Food Science and Nutrition, 41, 766-773. http://dx.doi.org/10.3746/jkfn.2012.41.6.766

[13] Park, W.Y., Ro, J.S. and Lee, K.S. (2001) Hypoglycemic Effect of Cudrania tricuspidata Root Bark. Korean Journal of Pharmacognosy, 32, 248-252.

[14] Oh, P.S., Lee, H.J. and Lim, K.T. (2009) Inhibitory Effect of Glycoprotein Isolated from Cudrania tricuspidata Bureau on Histamine Release and COX-2 Activity in RBL-2H3 Cells. Korean Journal of Food Science and Technology, 41, 405-412.

[15] Park, B.H., Back, K.Y., Lee, S.I. and Kim, S.D. (2008) Quality and Antioxidative Characteristics of Cudrania tricuspidata Leaves Tea. Korean Journal of Food Preservation, 15, 461-468.

[16] Chon, I.J., Lee, S.W., Cha, J.H., Han, J.H. and Whang, W.K. (2005) Anti-Oxidant Compounds of Cudrania tricuspidata Leaves. Yakhak Hoeji, 49, 416-421.

[17] Jeong, C.H., Choi, G.N., Kim, J.H., Kwak, J.H., Heo, H.J., Shim, K.H., Cho, B.R., Bae, Y.I. and Choi, J.S. (2009) In Vitro Antioxidative Activities and Phenolic Composition of Hot Water Extract from Different Parts of Cudrania tricuspidata. Preventive Nutrition and Food Science, 14, 283-289. http://dx.doi.org/10.3746/jfn.2009.14.4.283

[18] Han, X.H., Hong, S.S., Jin, Q., Li, D., Kim, H.-K., Lee, J., Kwon, S.H., Lee, D., Lee, C.-K., Lee, M.K. and Hwang, B.Y. (2009) Prenylated and Benzylated Flavonoids from the Fruits of Cudrania tricuspidata. Journal of Natural Products, 72, 164-167. http://dx.doi.org/10.1021/np800418j

[19] Kim, Y.C., Hur, J., Sohn, D.H. and Kim, H.S. (2008) Antibacterial Compounds of the Root Barks of Cudrania tricuspidata. Korean Journal of Pharmacognosy, 39, 246-248.

[20] Kim, S.H., Kim, N.J., Choi, J.S. and Park, J.C. (1993) Determination of Flavonoid by HPLC and Biological Activities from the Leaves of Cudrania tricuspidata Bureau. Journal of the Korean Society of Food Science and Nutrition, 22, 68-72.

[21] Park, J.C., Young, H.S. and Choi, J.S. (1992) Constituents of Cudrania tricuspidata in Korea. Yakhak Hoeji, 36, 40-45.

[22] Lee, H., Ha, H., Lee, J.K., Seo, C.S., Lee, N.H., Jung, D.Y., Park, S.J. and Shin, H.K. (2012) The Fruits of Cudrania tricuspidata Suppress Development of Atopic Dermatitis in NC/Nga Mice. Phytotherapy Research, 26, 594-599. http://dx.doi.org/10.1002/ptr.3577

[23] Yamamoto, M., Haruna, T., Yasui, K., Takahashi, H., Iduhara, M., Takaki, S., Deguchi, M. and Arimura, A. (2007) A Novel Atopic Dermatitis Model Induced by Topical Application with Dermatophagoides farinae Extract in NC/Nga Mice. Allergology International, 56, 139-148. http://dx.doi.org/10.2332/allergolint.O-06-458

[24] Leung, D.Y., Hirsch, R.L., Schneider, L., Moody, C., Takaoka, R., Li, S.H., Meyerson, L.A., Mariam, S.G., Goldstein, G. and Hanifin, J.M. (1990) Thymopentin Therapy Reduces the Clinical Severity of Atopic Dermatitis. The Journal of Allergy and Clinical Immunology, 85, 927-933. http://dx.doi.org/10.1016/0091-6749(90)90079-J

[25] Yamaguchi, T., Maekawa, T., Nishikawa, Y., Nojima, H., Kaneko, M., Kawakita, T., Miyamoto, T. and Kuraishi, Y. (2001) Characterization of Itch-Associated Responses of NC Mice with Mite-Induced Chronic Dermatitis. Journal of Dermatological Science, 25, 20-28. http://dx.doi.org/10.1016/S0923-1811(00)00099-2

[26] Administration KFD (2010) The Guideline for Effect Tests of Herbal Medicines: Atopic Dermatitis. In: Department of Bio-Herbal Medicine KFDA, Ed., Korean Food and Drug Administration, Seoul, 1-14.

[27] Damsgaard, T.E., Olesen, A.B., Sørensen, F.B., Thestrup-Pedersen, K. and Schiøtz, P.O. (1997) Mast Cells and Atopic Dermatitis. Stereological Quantification of Mast Cells in Atopic Dermatitis and Normal Human Skin. Archives of Dermatological Research, 289, 256-260. http://dx.doi.org/10.1007/s004030050189

[28] Internet Pathology Laboratory (2011) Mast Cells-O TOLUIDINE Blue. http://www-medlib.med.utah.edu/WebPath/webpath.html

[29] Leung, D.Y.M. (2006) New Insights into the Complex Gene-Environment Interactions Evolving into Atopic Dermatitis. The Journal of Allergy and Clinical Immunology, 118, 37-39. http://dx.doi.org/10.1016/j.jaci.2006.04.045

[30] Kawakami, T., Ando, T., Kimura, M., Wilson, B.S. and Kawakami, Y. (2009) Mast Cells in Atopic Dermatitis. Current Opinion in Immunology, 21, 666-678. http://dx.doi.org/10.1016/j.coi.2009.09.006

[31] Matsuda, H., Watanabe, N., Geba, G.P., Sperl, J., Tsudzuki, M., Hiroi, J., Matsumoto, M., Ushio, H., Saito, S., Askenase, P.W. and Ra, C. (1997) Development of Atopic Dermatitis-Like Skin Lesion with IgE Hyperproduction in NC/ Nga Mice. International Immunology, 9, 461-466. http://dx.doi.org/10.1093/intimm/9.3.461

[32] Park, S., Lee, J.B. and Kang, S. (2012) Topical Application of Chrysanthemum indicum L. Attenuates the Development of Atopic Dermatitis-Like Skin Lesions by Suppressing Serum IgE Levels, IFN-gamma, and IL-4 in Nc/Nga 
Mice. Evidence-Based Complementary and Alternative Medicine, 2012, Article ID: 821967. http://dx.doi.org/10.1155/2012/821967

[33] Van Bever, H.P. (1992) Recent Advances in the Pathogenesis of Atopic Dermatitis. European Journal of Pediatrics, 151, 870-873. http://dx.doi.org/10.1007/BF01954120

[34] Cikler, E., Ersoy, Y., Cetinel, S. and Ercan, F. (2009) The Leukotriene d4 Receptor Antagonist, Montelukast, Inhibits Mast Cell Degranulation in the Dermis Induced by Water Avoidance Stress. Acta Histochemica, 111, 112-118. http://dx.doi.org/10.1016/j.acthis.2008.04.006

[35] Seo, Y.M. and Jeong, S.H. (2015) Effects of Blending Oil of Lavender and Thyme on Oxidative Stress, Immunity, and Skin Condition in Atopic Dermatitis Induced Mice. Journal of Korean Academy of Nursing, 45, 367-377. http://dx.doi.org/10.4040/jkan.2015.45.3.367

[36] Cikler, E., Ercan, F., Cetinel, S., Contuk, G. and Sener, G. (2009) The Protective Effects of Melatonin against Water Avoidance Stress-Induced Mast Cell Degranulation in Dermis. Acta Histochemica, 106, 467-475. http://dx.doi.org/10.1016/j.acthis.2004.10.001

[37] Elias, P.M. and Schmuth, M. (2009) Abnormal Skin Barrier in the Etiopathogenesis of Atopic Dermatitis. Current Opinion in Allergy \& Clinical Immunology, 9, 437-446. http://dx.doi.org/10.1097/ACI.0b013e32832e7d36

[38] Yamashita, H., Tasaki, D., Makino, T., Matsuoka, K., Nose, M., Inagaki, N. and Mizukami, H. (2009) The Role of IgE and Repeated Challenge in the Induction of Persistent Increases in Scratching Behavior in a Mouse Model of Allergic Dermatitis. European Journal of Pharmacology, 605, 153-157. http://dx.doi.org/10.1016/j.ejphar.2009.01.006

[39] Cowden, J.M., Zhang, M., Dunford, P.J. and Thurmond, R.L. (2010) The Histamine $\mathrm{H}_{4}$ Receptor Mediates Inflammation and Pruritus in Th2-Dependent Dermal Inflammation. Journal of Investigative Dermatology, 130, 1023-1033. http://dx.doi.org/10.1038/jid.2009.358

\section{Submit or recommend next manuscript to SCIRP and we will provide best service for you:}

Accepting pre-submission inquiries through Email, Facebook, LinkedIn, Twitter, etc.

A wide selection of journals (inclusive of 9 subjects, more than 200 journals)

Providing 24-hour high-quality service

User-friendly online submission system

Fair and swift peer-review system

Efficient typesetting and proofreading procedure

Display of the result of downloads and visits, as well as the number of cited articles

Maximum dissemination of your research work

Submit your manuscript at: http://papersubmission.scirp.org/ 